HELMINTHOLOGIA, 53, 3: 243 - 247, 2016

\title{
A long-term survey of Fascioloides magna in red deer (Cervus elaphus) in Slovakia (Danube floodplain forests) during the period of $2005-2015$
}

\author{
E. BAZSALOVICSOVÁ ${ }^{1 *}$, M. ŠPAKULOVÁ1', L'. JUHÁSOVÁ1, Š. MIHOLICS², D. RAJSKÝ', I. KRÁLOVÁ-HROMADOVÁ1
}

${ }^{1}$ Institute of Parasitology, Slovak Academy of Sciences, Hlinkova 3, 04001 Košice, Slovakia; *E-mail: bazsal@saske.sk; ${ }^{2}$ Regional Veterinary and Food Administration in Komárno, Štúrova 5, 94501 Komárno, Slovakia; ${ }^{3}$ Faculty of Forestry, Technical University in Zvolen, T. G. Masaryka 20, 96053 Zvolen, Slovakia

Article info

Received April 18, 2016 Accepted June 17, 2016

\begin{abstract}
Summary
Fascioloidosis of wild and domestic ruminants is caused by giant liver fluke, Fascioloides magna (Trematoda; Fasciolidae). In Slovakia, the parasite is present in the Danube floodplain forests permanent focus for almost 30 years. Here we provide data on 11-year survey of $F$. magna acquired from 137 red deer (Cervus elaphus) hunted in the southwestern hunting grounds (districts Komárno and Dunajská Streda). Almost $47 \%$ of all examined deer, including males, females and fawns, were infected with $F$. magna. During the studied period, the prevalence ranged between $33.3 \%$ (2009) and $63.6 \%$ (2007). Prevalence of fascioloidosis varied between sexes and age categories; while the lowest overall prevalence was detected in females $(33.3 \%)$, higher values were documented for red deer males (50.6\%) and fawns (43.3\%). A presence of giant liver fluke in studied regions of southwestern Slovakia deserves future attention and ongoing monitoring due to a possible threat of $F$. magna infection of domestic ruminants in overlapping regions. Keywords: fascioloidosis; prevalence; intensity of infection; red deer; liver; pathology
\end{abstract}

\section{Introduction}

The giant liver fluke, Fascioloides magna (Bassi, 1875) (Trematoda; Fasciolidae) is a liver parasite of free-living and domestic ruminants. The parasite is of North American origin and it was introduced into Europe in the $19^{\text {th }}$ century where it has established three permanent natural foci; 1) La Mandria Regional Park in the northern Italy; 2) Czech Republic and southwestern Poland; and 3) Danube floodplain forests, involving Austria, Slovakia, Hungary, Croatia and Serbia (for review see Králová-Hromadová et al., 2015). The Danube floodplain forests (DFF) represent the latest and still expanding European natural focus; it is a unique biotope located on inlands of the inland delta of the Danube River. The very first detection of fascioloidosis in DFF originated from the Lower Austria, where F. magna was found in fallow deer (Dama dama) from game husbandry (Pfeifer, 1983). Soon after, Rajský et al. (1994) documented the first record of giant liver fluke in Slovakia. In the same time, Majoros and Sztojkov (1994) published data on the first occurrence of $F$. magna in red deer (Cervus elaphus) in northwestern region of Hungary named Szigetköz. Suitable ecological conditions for the principal intermediate snail host of F. magna (Galba truncatula), and the fact that the large trans-border wetland area of DFF lacks natural or human barriers for the movement of cervids, have resulted in a spread of $F$. magna down the Danube River. Consequently, giant liver fluke was detected in Baranja region, northeastern Croatia (Marinculić et al., 2002) and in Serbia (Marinković et al., 2013). Since the first findings of the parasite in the respective countries, F. magna has been commonly reported in all mentioned European regions within the Danube floodplain forests (for review see Králová-Hromadová et al., 2016). Studies on population genetics of European populations of $F$. magna using mitochondrial (Králová-Hromadová et al., 2008) and 
microsatellite (Minárik et al., 2014; Juhásová et al., unpublished data) markers revealed that giant liver fluke in DFF represents same genetic pool. Besides, the molecular study based on mitochondrial data revealed two independent phylogenetic lineages of F. magna in Europe; Italian population was found to be genetically specific and distinct from two other European populations. It was confirmed that F. magna did not spread further to Europe from Italy what indicated multiple introductions of the parasite to Europe (Králová-Hromadová et al., 2011).

Since the first discovery of $F$. magna in Slovakia in 1988, the occurrence of the parasite in wild ruminants, in particular red deer and roe deer (Capreolus capreolus), has been regularly monitored in the whole territory alongside the Danube River (Špakulová et al., 2003). Prevalence and intensity of infection have gradually increased with the maximum values $(91.3 \%$ in red deer; $60 \%$ in roe deer) in 1995 (Rajský et al., 2002). While low intensity of infection was detected in majority of infected animals, increased values were observed in older individuals (Rajský et al., 2002). In Slovakia, F. magna currently occurs in the entire area of floodplain forests along waterside of the Danube River and in the Danubian islands southward from the Gabčíkovo waterworks.

The aim of this study was to summarize numerous data acquired in the 11-year monitoring in order to interpret the status of fascioloidosis in southwestern Slovakia in the last decade. Therefore, the prevalence and intensity of infection of $F$. magna in cervids in the Danube region in several hunting grounds in Slovakia was determined during the period of 2005 - 2015. Long-term monitoring of fascioloidosis provided first comprehensive insight into the occurrence of $F$. magna in red deer from different localities belonging to districts of Komárno and partially Dunajská Streda. The data were related to the knowledge on anthelmintic treatment of fascioloidosis in the studied area.

\section{Material and Methods}

In the period of $2005-2015,137$ livers retrieved from the hunted red deer were examined for the presence of F. magna. Samples originated from 19 different localities of Danube floodplain forests in southwestern part of Slovakia, belonging into districts of Komárno and Dunajská Streda (for details see Fig. 1). After dissection of deer, livers were immediately frozen at $-20^{\circ} \mathrm{C}$ and delivered to the Institute of Parasitology, Košice. Livers were cut into $1 \mathrm{~cm}$ wide slices and parasites were identified based on their morphology and localization in fibrous pseudocysts. Total number of pseudocysts and flukes in each liver were documented. The intensity of infection and prevalence were calculated. Parasites were washed in physiological solution and preserved in $96 \%$ ethanol. The flukes from respective cysts were fixed together due to future genetic studies of infrapopulations of giant liver fluke from DFF.

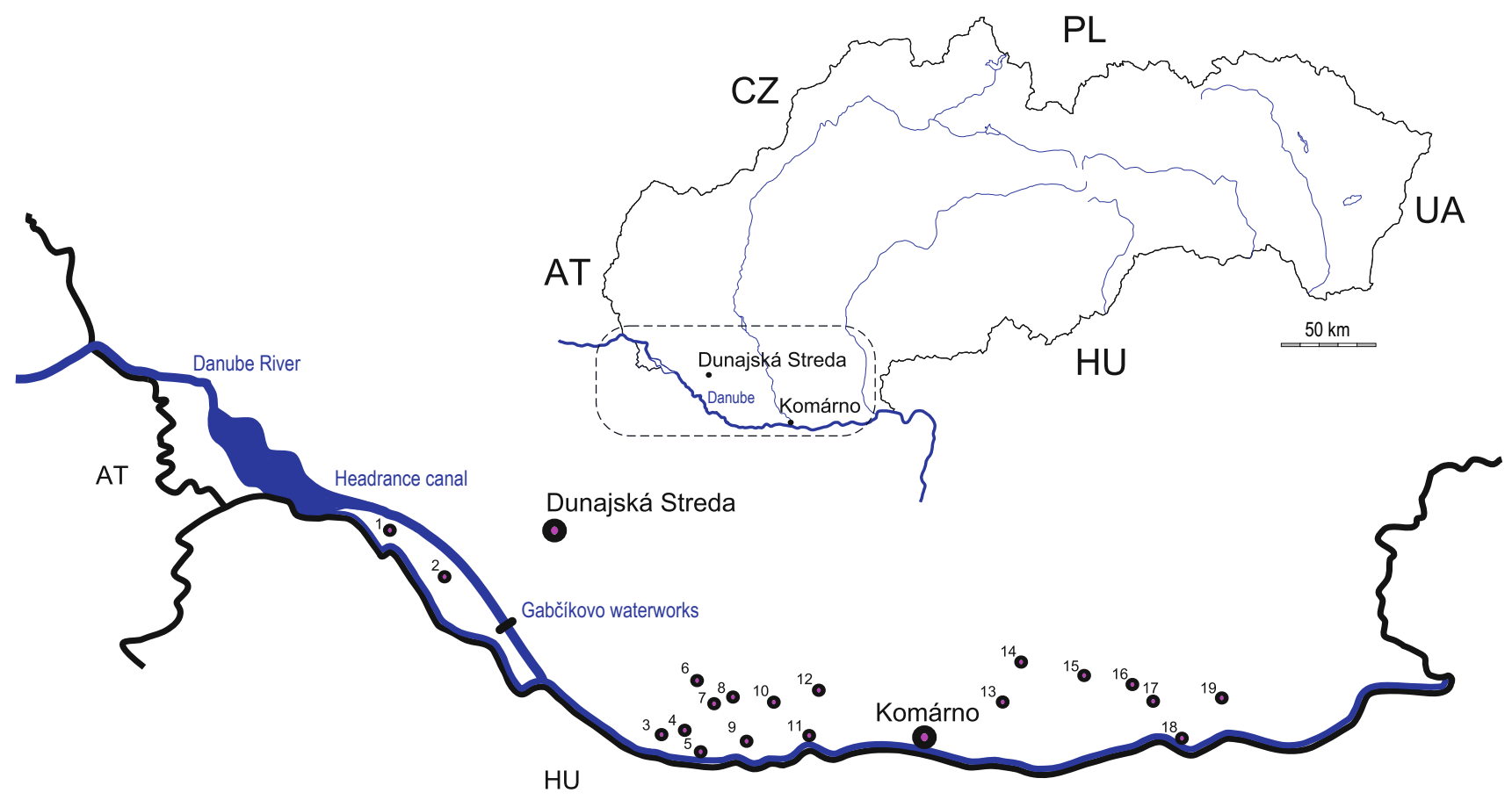

Fig. 1. Geographic origin of Fascioloides magna from southwestern Slovakia analyzed in current study. 1 - Vojka nad Dunajom, 2 - Bodíky, 3 - Číčov, 4 - Trávnik, 5 - Kližská Nemá, 6 - Holiare, 7 - Tôň, 8 - Zemianska Olča, 9 - Vel'ké Kosihy, 10 - Okoličná na Ostrove, 11 - Zlatná na Ostrove, 12 - Čalovec, 13 - Chotín, 14 - Svätý Peter, 15 - Modrany, 16 - Bátorové Kosihy, 17 - Búč, 18 - Kravany nad Dunajom, 19 - Svätý Juraj, Pereš. The respective localities were visualized using the DIVA-GIS available from http://www.diva-gis.org 


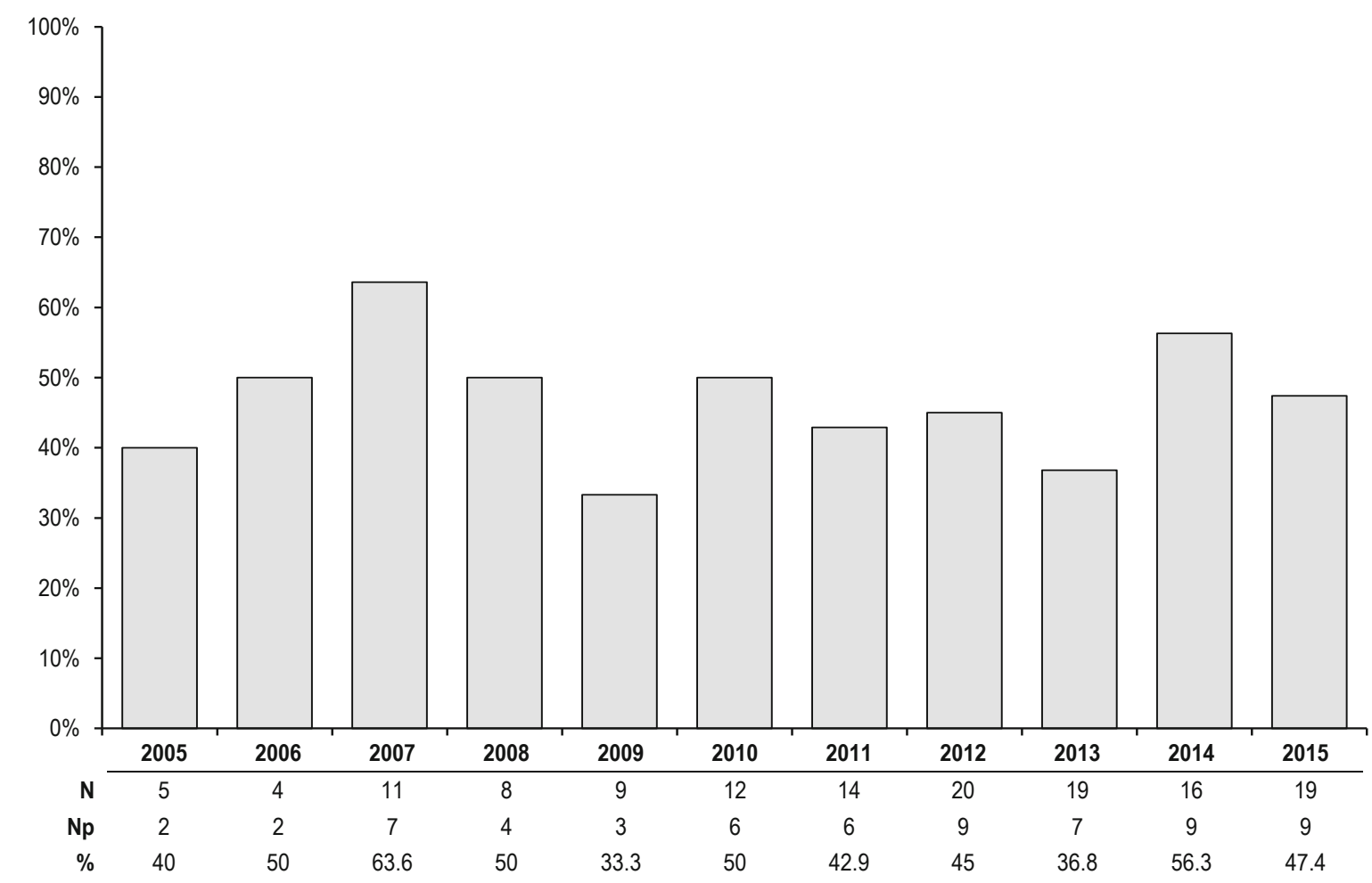

Fig. 2. Prevalence of Fascioloides magna in red deer in southwestern Slovakia in the respective years during the period of 2005-2015. N- number of examined red deer, $\mathrm{Np}$ - number of red deer infected with F. magna, \% - prevalence of fascioloidosis

\section{Results and Discussion}

Out of 137 livers examined, 64 (46.7 \%) of them were found to be infected with $F$. magna. The number of cysts within the livers varied from one to more than 40 . Most pseudocysts contained two and more (up to 6) adult flukes; however, some of them were filled with amorphous material with the absence of flukes. The lowest prevalence $(33.3 \%)$ was documented in 2009, while in 2007 the overall prevalence reached up to $63.6 \%$ (Fig. 2). Prevalence of fascioloidosis varied between sexes and age categories; while the lowest overall prevalence was detected in red deer females (33.3 \%), higher values were documented for males $(50.6 \%)$ and fawns (43.3\%) (Fig. 3). The most frequent number of flukes found within infected livers was $1-25$ flukes that were determined in $38.2 \%$ males, $16.7 \%$ females and $43.3 \%$ of fawns. The total number of $26-50$ and $51-75$ flukes per liver was found in $2.3 \%$ and $2.2 \%$ of males, respectively and congruently in $5.5 \%$ of females. The higher number of flukes $(76-200)$ was found in males ( $4.5 \%$ and $3.4 \%$ ) and females (5.6\%); fawns were never found to be infected with higher number of flukes than 25 . Regarding the individual parasite burden, the maximum number of 180 flukes was detected in the liver of four-year old red deer female hunted in the locality Č́čcov in 2007. In addition, 124 flukes were found in liver of three-year old red deer male from Vel'ké Kosihy in 2008, and $111 / 112$ flukes were obtained from two red deer male hunted in Čícov in 2010 and 2015, respectively. The higher values of overall prevalence detected in red deer males can be closely related with frequent migration/swimming across the Danube River, especially during the mating season, what can result in their wider geographic range. On the other hand, distribution of red deer females and their migration pattern is more restricted what reduces the risk of F. magna infection.

We were interested in a relation of presented data on $F$. magna prevalence in southwestern Slovakia with a dynamics of fascioloidosis in the Danube region and differences in prevalence before, during and after anthelmintic treatment. In general, a fluctuating pattern of $F$. magna prevalence has been observed; at the beginning, the high values $(90-95 \%)$ were documented at the time of its outbreak (e.g. Rajský et al., 1994; Majoros \& Sztojkov, 1994), dropping significantly $(20-40 \%)$ during the treatment programme (Giczi, 2008), and gradually increasing after the therapy during the period without anthelmintic control, being stabilized at relatively constant levels (e.g. 50 - 60 \%; Severin et al., 2012; Marinković et al., 2013).

In Slovakia, a prevalence of fascioloidosis in red deer in a period of its outbreak was $70-95 \%$ (Rajský et al., 1994) and gradually decreased from $66.6 \%$ down to $31.3 \%$ in the period of anthelmintic treatment programme (Rajský et al., 1998; 2002). According to our results on prevalence of fascioloidosis in a course of $2005-2015$ $(33.3-63.6 \%)$, F. magna is present during the whole monitoring period at the same levels of prevalence as it was observed during the dehelmintization in 1996 - 2004 (Rajský et al., 1998; 2002; 


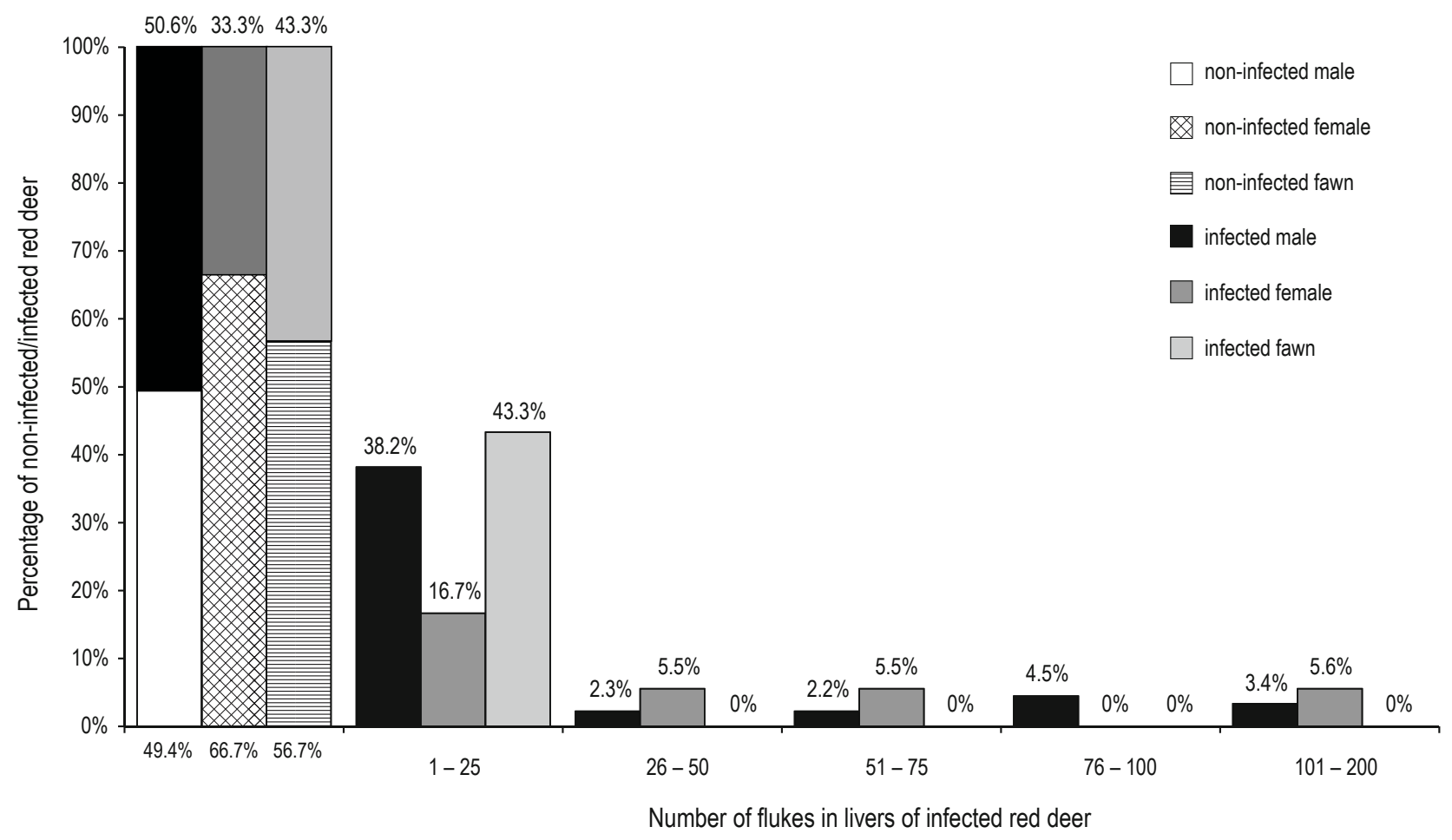

Fig. 3. Intensity of Fascioloides magna infection in red deer in southwestern Slovakia during the period of $2005-2015$

Bieliková, 2015). However, it is very surprising finding because dehelmintization programme applied in certain hunting grounds in Slovakia and Hungary started in 1996 and was definitely finished in 2004 mainly due to economic and management reasons. On the other hand, the impact of therapeutic drugs can not be completely excluded due to possible medical treatment in countries neighbouring Slovakia within DFF.

In conclusion, the Danube River plays an important role in the spread of fascioloidosis in the natural DFF focus. The geographical range of wild ruminants infected with $F$. magna is still expanding along the Danube River, as well as into the surrounding regions. There is a high risk that the parasite will be determined in further countries down the Danube River (e.g. Bulgaria, Romania), or in neighbouring countries such as Bosna and Herzegovina (Sinanović et al., 2013). Since the Danube floodplain forests represent so far the only European natural focus with no documented F. magna infection in domestic ruminants, monitoring programme should be conducted in order to ensure constant control of this parasitosis.

\section{Acknowledgement}

This work was supported by the Slovak Grand Agency VEGA (project VEGA no. 2/0133/13), Bilateral Mobility Project SAS-ASCR 1620 and Centre of Excellence for Parasitology (ITMS26220120022; 0.8) supported by the Research \& Development Operational Programme funded by the European Regional Development Fund.

\section{References}

BieliKovÁ, Z. (2015): Management of deer breeding in the area of JI Podunajská in relation to fascioloidosis. Attestation thesis, Košice, Slovakia: Institute of Postgraduate Education of Veterinary Surgeons (In Slovak)

Gıczı, E. (2008): Fascioloides magna (Bassi, 1875) infection of Hungarian red deer and roe deer stock and the possibility of protection. PhD thesis, Hungary, Sopron: University of West Hungary Králová-Hromadová, I., Špakulová, M., HoráčKová, E., Turčeková, L'., Novobilský, A., Beck, R., Koudela, B., Marinculić, A., RajskÝ, D., Pyвus, M. (2008): Sequence analysis of ribosomal and mitochondrial genes of the giant liver fluke Fascioloides magna (Trematoda: Fasciolidae): intraspecific variation and differentiation from Fasciola hepatica. J Parasitol., 94: 58 - 67. DOI: 10.1645/GE-1324.1 Králová-Hromadová, I., Bazsalovicsová, E., Štefka, J., Špakulová, M., Vávrová, S., Szemes, T., Tkach, V., Trudgett, A., Pybus, M. (2011): Multiple origins of European populations of the giant liver fluke Fascioloides magna (Trematoda: Fasciolidae), a liver parasite of ruminants. Int. J. Parasitol., 41(3 - 4): 373 - 383. DOI: 10.1016/j.jpara.2010.10.010

Králová-Hromadová, I., Bazsalovicsová, E., Demiaszkiewicz, A. (2015): Molecular characterization of Fascioloides magna (Trematoda: Fasciolidae) from south-western Poland based on mitochondrial markers. Acta Parasitol., 60(3): 544 - 547. DOI: 10.1515/ ap-2015-0077 
Králová-Hromadová, I., Juhásová, L'., Bazsalovicsová, E. (2016): The Giant Liver Fluke, Fascioloides magna: Past, present and future research. Heidelberg, Germany, Springer International Publishing, $106 \mathrm{pp}$.

MAjoros, G., Sztojkov, V. (1994): Appearance of the American liver fluke Fascioloides magna (Bassi, 1875) (Trematoda: Fasciolata) in Hungary. Parasitol. Hungaria, 27: $27-38$

Marinculić, A., DŽakUla, N., JanICKI, Z., HaRdY, Z., LuČInger, S., ŽIVIČNJAK, T. (2002): Appearance of American liver fluke (Fascioloides magna, Bassi, 1875) in Croatia - a case report. Vet. Arhiv, 72(6): $319-325$

Marinković, D., KukolJ, V., Aleksić-Kovačević, S., Jovanović, M., KNEŽEVIĆ, M. (2013): The role of hepatic myofibroblasts in liver cirrhosis in fallow deer (Dama dama) naturally infected with giant liver fluke (Fascioloides magna). BMC Vet. Res., 9: 45. DOI: 10.1186/1746-6148-9-45

MinÁRIK, G., BazsalovicsovÁ, E., Zvijáková, L'., Štefka, J., Pálková, L., KRÁlovÁ-Hromadová, I. (2014) Development and characterization of multiplex panels of polymorphic microsatellite loci in giant liver fluke Fascioloides magna (Trematoda: Fasciolidae), using next-generation sequencing approach. Mol. Biochem. Parasitol., 195: 30 - 33. DOI: 10.1016/j.molbiopara.2014.06.003
Pfeiffer, H. (1983): Fascioloides magna: Erster Fund in Österreich. Wien. Tierarztl. Monat., 70: 168 - 170

RajskY, D., Patus, A., Bukovjan, K. (1994): The first finding of Fascioloides magna (Bassi, 1875) in Slovakia. Slov. Vet. Čas., 19: 29 - 30 (In Slovak)

RajskÝ, D., Áč, P., Ferenčík, I. (1998): Species diversity of game in the region of Gabčikovo water work in terms of the population variations and disease prevention. Slov. Vet. Čas., 23(6): $309-$ 313 (In Slovak)

RajskÝ, D., Čorba, J., VÁrady, M., Špakulová, M., CabadaJ, R. (2002): Control of fascioloidosis (Fascioloides magna Bassi, 1875) in red deer and roe deer. Helminthologia, 39(2): 67 - 70

Severin, K., Mašek, T., Janicki, Z., Konjević, D., Slavica, A., Marinculić, A., Martinković, F., Vengušt, G., Dżaja, P. (2012): Liver enzymes and blood metabolites in a population of free-ranging red deer (Cervus elaphus) naturally infected with Fascioloides magna. J. Helminthol., 86: 190 - 196. DOI: 10.1017/S0022149X1100023X Sinanović, N., Omeragić, J., ZuKo, A., Jažıć, A. (2013): Impact of deer migration on spread of giant American fluke (Fascioloides magna) in Bosna a Herzegovina. Veterinaria, 62: 213 - 222

ŠPakUlovÁ, M., RAJSkÝ, D., Sokol, J., VodŇANSKÝ, M. (2003): Giant liver fluke (Fascioloides magna), an important liver parasite of ruminants. Bratislava, Slovakia, PaRPRESS, 61 pp. 